\title{
Introducing New Guidelines on Geoheritage Conservation in Protected and Conserved Areas
}

\author{
Roger Crofts ${ }^{1,2}$ (D) Dan Tormey ${ }^{3} \cdot$ John E. Gordon ${ }^{4}$
}

Received: 4 December 2020 / Accepted: 11 March 2021 / Published online: 31 March 2021

(C) The Author(s) 2021

\begin{abstract}
This paper introduces newly published guidelines on geoheritage conservation in protected and conserved areas within the "IUCN WCPA Best Practice Guidelines" series. It explains the need for the guidelines and outlines the ethical basis of geoheritage values and geoconservation principles as the fundamental framework within which to advance geoheritage conservation. Best practice in establishing and managing protected and conserved areas for geoconservation is described with examples from around the world. Particular emphasis is given to the methodology and practice for dealing with the many threats to geoheritage, highlighting in particular how to improve practice for areas with caves and karst, glacial and periglacial, and volcanic features and processes, and for palaeontology and mineral sites. Guidance to improve education and communication to the public through modern and conventional means is also highlighted as a key stage in delivering effective geoconservation. A request is made to geoconservation experts to continue to share best practice examples of developing methodologies and best practice in management to guide non-experts in their work. Finally, a number of suggestions are made on how geoconservation can be further promoted.
\end{abstract}

Keywords Geoheritage $\cdot$ Geoconservation $\cdot$ Protected and conserved areas $\cdot$ Best practice guidelines

\section{Introduction}

The IUCN World Commission on Protected Areas (WCPA) instituted Best Practice Guidelines in the 1990s to help protected area managers and staff in their work. Thirty-two guidelines have been produced covering key topics of ongoing or emerging concern that challenge protected area managers (https://www.iucn. org/theme/protected-areas/resources/iucn-wcpa-best-practiceguidelines-protected-area-managers-series). None, however, deals with the conservation of geoheritage, a fundamental component of nature. To address this deficiency, the Geoheritage Specialist Group of WCPA gained agreement from WCPA to develop guidelines on this subject under the leadership of Roger Crofts, a former research geomorphologist

Roger Crofts

Musselburgh, Scotland, UK

School of Geosciences, University of Edinburgh, Edinburgh, UK

Catalyst Environmental Solutions, Santa Monica, CA, USA

School of Geography and Sustainability, University of St Andrews, St Andrews, Scotland KY16 9AL, UK and protected area organisation leader. The resulting guidance (Crofts et al. 2020) has now been released in PDF and can be freely downloaded at https://doi.org/10.2305/IUCN.CH.2020. PAG.31.en. The aim of this paper is to outline the purpose, scope, and content of the "Geoconservation Guidelines" and to promote their use (Fig. 1).

The guidelines are intended to help improve the conservation and management of geoheritage and geodiversity in protected and conserved areas, and the recognition of the interrelationships and interactions with biological features and processes. They are not a textbook on geoconservation management practice, but rather set out the essential background, context, and principles; summarise relevant material to make it more readily accessible to users in one volume; and provide links to the key literature and additional sources that include detailed practical guidance. In order to focus attention on delivering improved performance, 22 best practice guidelines are articulated. There is an extensive glossary of terms to help the reader and also to ensure that the IUCN community more widely has a better understanding of the terms and concepts underlying geoheritage conservation. Specific examples from around the world are included along with over 150 photographs explaining best and not-so-good practice. 
Fig. 1 Front cover of the IUCN WCPA Best Practice Protected Area Guidelines Series No. 31: Guidelines for geoconservation in protected and conserved areas

\section{IUCN}

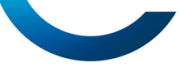

\section{Guidelines for geoconservation in protected and conserved areas}

Crofts, R., Gordon, J.E., Brilha, J., Gray, M., Gunn, J., Larwood, J., Santucci, V.L., Tormey, D., and Worboys, G.L.

\section{Craig Groves, Series Editor}

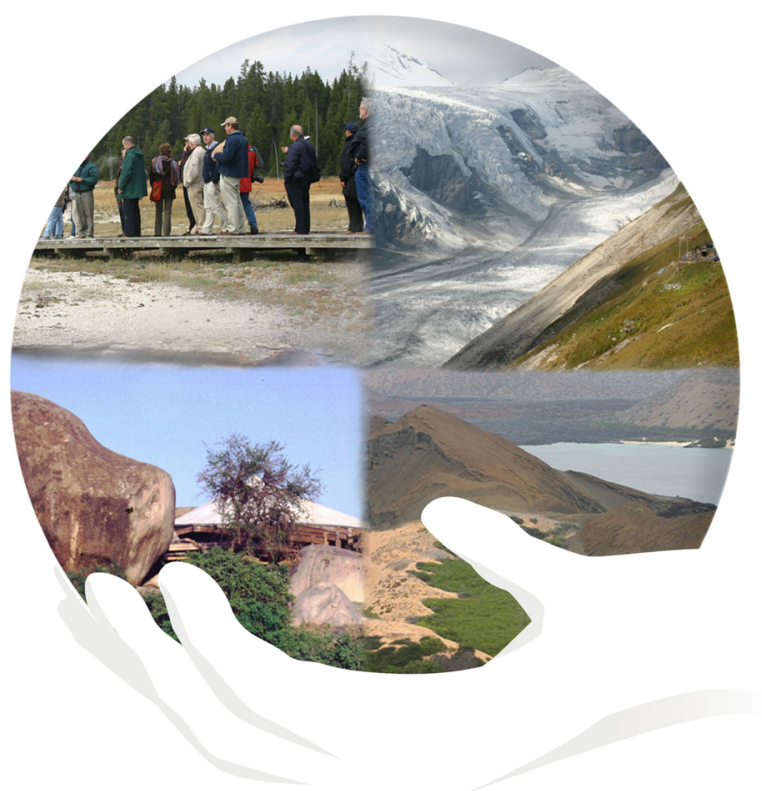

\section{Developing capacity for a protected planet}

\section{Best Practice Protected Area Guidelines Series No. 31}

\section{(5) WCPA}
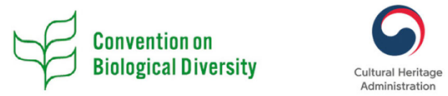

\section{Need for Guidance on Geoconservation}

There are a number of reasons why these guidelines are needed (Crofts 2014, 2018; Crofts and Gordon 2014, 2015).

Many protected area professionals and custodians of conserved areas are not geoscientists and may find the language and concepts of the Earth sciences difficult to understand and incorporate in their work. This is understandable as the terminology is not well understood by non-Earth scientists, and the concepts are quite different from those of biodiversity conservation, for which many protected areas have been established.

Another reason is the assumption that geological features are relatively static and need very little attention. As geoheritage experts, readers of this journal will know that this is not the case. For example, there are many instances where there is thoughtless removal of rare fossils or minerals, trampling of fragile volcanic features, and quarrying of sand and gravel and rock to provide aggregate for construction. 
Geoheritage is often overlooked in protected area conservation and management, but may have high value as an integral part of nature and therefore need to be understood and looked after. In addition, in a protected area, there may be significant geological features, which are of interest to visitors, and which might also represent significant natural hazards (such as volcanic activity) that must be properly addressed by management staff.

More fundamentally, there is a widespread perception that conservation of nature equates exclusively to biodiversity conservation, as reflected for example in the work programmes of the IUCN over recent quadrenniums. However, the functional health of many protected areas depends on understanding the non-biological processes that have created the area, are operating at the present time, and may be influential in the future.

Underlying this perception is the fact that nature conservation internationally has involved a species-driven approach since the middle of the twentieth century. This was re-enforced by the international agreement of the Convention on Biological Diversity (CBD) at the Earth Summit in 1992 focussing entirely on biodiversity and with no reference in that Convention, or the others enacted at the same time, to geodiversity or geoconservation. The CBD triggered the need for national and local Biodiversity Action Plans, but there is no similar requirement for geodiversity action plans. It is left to individual nations to make their own arrangements and many still do not. The lack of international conventions and agreements on geodiversity and geoheritage contributes to an absence of statutory protection tools in many countries and, consequently, makes geoconservation difficult to prioritise compared with biodiversity conservation by national nature conservation agencies and managers. These and other reasons for the lack of status of geoconservation are spelt out in detail elsewhere (see in particular: Crofts 2014; Gordon et al. 2018).

Therefore, a major reason for producing geoconservation guidelines was to demolish these myths and demonstrate the need both for geoheritage conservation and for learning from best practice around the world.

Excellent guidance and many case studies have been produced in recent years and the material is increasing all the time, for example published in this journal and collated in Gray (2013) and Reynard and Brilha (2018). Much of this, however, is not easily accessible by protected area managers and staff, nor by the wider nature conservation community. Hence, it was important both to register the need for geoconservation within the scope of IUCN activities and to distil the existing corpus of knowledge and experience for the benefit of all. The use of best practice examples will hopefully give users renewed confidence in looking after geoheritage and in connecting geoconservation with biodiversity conservation.

The basis for change within IUCN came from agreement, after much argument, on the revised definition of a protected area established at the World Conservation Congress in Barcelona in 2008 and set out in the protected area management category guidance: "A clearly defined geographical space, recognised, dedicated and managed, through legal or other effective means, to achieve the long-term conservation of nature with associated ecosystem services and cultural values" (Dudley 2008). The operative word is "nature" in order to embrace abiotic, as well as biotic, nature and also to recognise the interconnections and interdependencies between them. Unpacking the definition in relation to geoconservation means the following: "long-term conservation of nature" also refers to geoconservation; sub-surface rocks and minerals, as well as surface features, are included. Management can, in practice, mean doing nothing in order to retain natural processes; managers should ensure that geoheritage features are not damaged and the processes forming them are not impaired; and managers will need to ensure that geoconservation and biodiversity conservation are linked.

This change was reinforced by Resolutions approved by successive General Assemblies of IUCN setting out programme elements on geoconservation (IUCN 2008, 2012, 2016 , 2020) and agreement to a programme on Key Geoheritage Areas (IUCN 2020).

\section{Target Audience}

The "Geoconservation Guidelines" are to help professionals working in and for protected and conserved areas to incorporate conservation and management of geoheritage and geodiversity into their work at all scales from the system level to the site level. They are written as far as possible in non-technical language. To help apply these guidelines in specific situations, the working assumption is that further advice will be available, on a contractual basis or through volunteer input, to the non-specialist staff in protected and conserved areas from those with knowledge and experience in conservation and protection of geoheritage. Figure 2 provides a guide to the document.

\section{Geoconservation Values and Principles}

It is important for readers of the guidelines to understand the intellectual basis for geoconservation as a set of values and to place these within an overall framework. As geodiversity and geoconservation lack an international convention akin to the Convention on Biological Diversity, the Declaration of the Rights of the Memory of the Earth, termed the Digne Declaration 1991 (Martini and Pagés 1994), interestingly promoted by ProGEO almost three decades ago, provides a cornerstone. The key values are intrinsic value; scientific and educational value; aesthetic, cultural, and spiritual value; ecological value in support of biodiversity and ecosystem functioning; and 
Fig. 2 Structure of the guidelines: key steps in establishing and managing geoheritage protected areas and the main topics covered
Geoconservation concepts, definitions and principles (Sections 2 and 3)
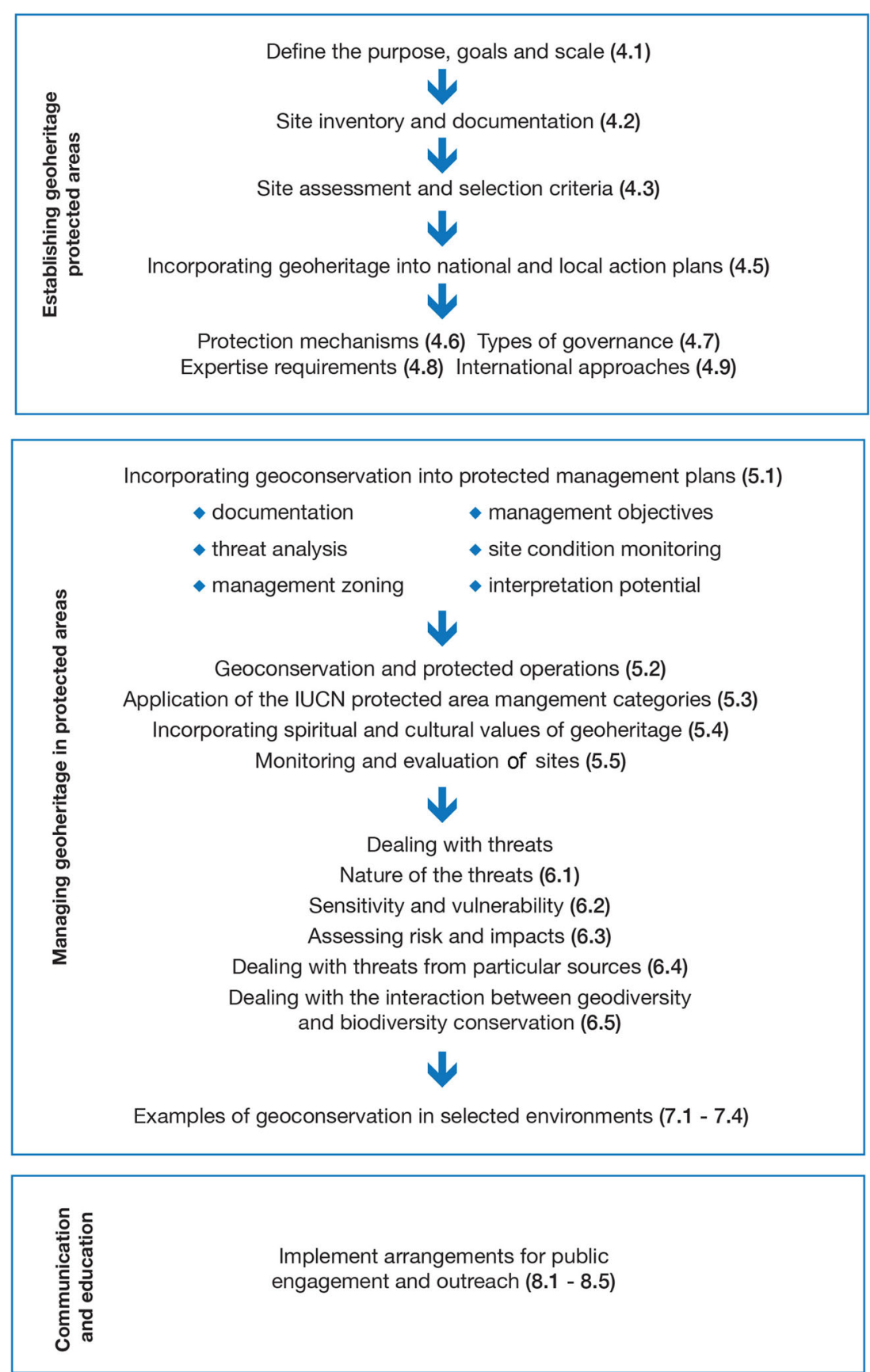

provision of environmental goods and ecosystem services. In addition, 9 guiding principles are set out (Table 1).

\section{Establishment of Protected and Conserved Areas}

In establishing de novo protected and conserved areas for conservation or adding a geoconservation component to existing areas, a stepwise approach is recommended (Fig. 2).
First, it is necessary to define the purpose of protection and to determine the operational scale: site, area, or wider. To aid this step, eight key categories of geoheritage interest are identified and examples provided (Table 2).

Second, an inventory should be made. We recommend using the schema developed by Brilha for these guidelines, based on earlier work (Brilha 2016, 2018; García-Cortés et al. 2019).

The third step is to determine the site assessment criteria. We recommend 4 main categories with subdivisions (Table 3 
Table 1 Key guiding principles for geoconservation

1 The multiple values of geodiversity and geoheritage should be recognised.

2 Effective geoconservation requires a rigorous and systematic approach to all aspects of site identification, assessment, management and monitoring.

3 Management of natural systems should 'work with nature', allowing for natural processes to operate over their full range of variability.

4 Natural systems and processes should be based on sound understanding, and managed in a spatially integrated manner.

5 Geoconservation strategies should include vulnerability and risk assessment.

6 The inevitability of natural change should be recognised.

7 The effects of global climate change should be assessed and acted on as far as achievable.

8 Natural systems should be managed within the limits of their capacity to absorb change.

9 The interaction and interdependency of geodiversity, biodiversity and cultural heritage should be recognised.

Source: Crofts et al. (2020)

Table 2 Key categories of geoheritage interests with examples

1 Key stages in Earth history: the GSSP site for the base of the Precambrian Ediacaran Period is located at Enorama Creek, Flinders Ranges National Park, South Australia. This is the only GSSP 'golden spike' in the Southern Hemisphere.

2 Major structural and tectonic features: Banff, Jasper, Kootenay and Yoho National Parks, Alberta and British Columbia, Canada, help protect the intensely folded southern section of the Canadian Rocky Mountains, a mountain area uplifted as a consequence of tectonic plate collision.

3 Types, occurrence and formation of minerals: Uranium-based minerals found in secondary and enriched water table deposits at Mount Painter in the Arkaroola Protection Area, South Australia, have yielded outstanding research and museum display specimens.

4 Rare rock types and rock structures: Mount Gee, the 'crystal mountain', which lies within the Arkaroola Protection Area of South Australia, is a product of volcanic activity. The silica-rich rock structures are where the molten rock flowed within the system and include caverns and cavities containing internationally rare crystals.

5 Evolution of life: Bletterbach Gorge in northern Italy, a protected area, includes a rock sequence that marks the Permian extinction event, the greatest mass extinction of life in Earth's history.

6 Contemporary Earth processes: Hawai'i Volcanoes National Park, USA, hosts a continuously active volcano with basaltic pahoehoe and aa lavas.

7 Representative surface and subsurface features: Deer Cave in the Gunung Mulu National Park in Malaysia is a World Heritage site that protects outstanding karst resources and provides visitor access to a suite of caves.

8 Records of past environmental conditions: Kosciuszko National Park in Australia features the Australian mainland's highest mountain and evidence of Pleistocene glaciation, with five glacial lakes, a glacial cirque and moraines.

Source: Crofts et al. (2020), adapted from Crofts and Gordon (2015)
Table 3 Site assessment criteria

\section{Scientific study}

Representativeness: how well the geosite illustrates an Earth process or feature and makes a meaningful contribution to the understanding of the topic, process, feature or framework;

Integrity: the present conservation status of the geosite, taking into account both natural processes and human factors;

Rarity: the number of geosites representing similar geological or geomorphological features;

Scientific knowledge: the extent of scientific information already published about the geosite.

2 Educational use

Educational potential: the capacity of a feature to be easily understood by students of different educational levels (primary and secondary schools, universities);

Geodiversity: the number of different types of geological and geomorphological features and processes present in the site;

Accessibility: the conditions of access to the site in terms of difficulty and safety, and the amount of time students and visitors would need to spend on foot in order to learn about the site;

Safety: related to the visiting conditions, taking into consideration minimum risk for students and visitors;

Cultural and spiritual connection: link to cultural and spiritual values held by indigenous communities.

3 Geotourism/recreational use

Scenery: the visual beauty of the landscape or feature;

Interpretive potential: the capacity of the feature to be easily understood by non-experts; Accessibility: the conditions of access to the site in terms of difficulty and safety, and the amount of time the general public would need to walk the site.

Source: Crofts et al. (2020)

and Fig. 3). Examples of different approaches used successfully around the world, such as the Geoheritage Tool Kit (Brocx and Semeniuk 2015), are provided.

The fourth step is to encourage the managers of protected and conserved areas to ensure that geoconservation is included in key decision documents and action plans at national, regional, and local scales.

A number of organisational and administrative matters need to be considered in the fifth and final step. Users are recommended to consider the range of protection mechanisms available in addition to traditional gazetted protected areas, such as the recently defined Other Effective Conservation Measures (IUCN/WCPA 2019) which now form part of the protected area programme of the Convention on Biological Diversity (CBD Decision 14/ 8 ); hence, the inclusion of "conserved areas" in the title of the guidelines. In developing geoconservation protected and conserved areas, particular attention should also be given to the appropriate type of governance. There are now many models, and IUCN guidance is available and provided in the guidelines (Borrini-Feyerabend et al. 2013; Borrini-Feyerabend and Hill 2015). The expertise requirements for establishing and managing 

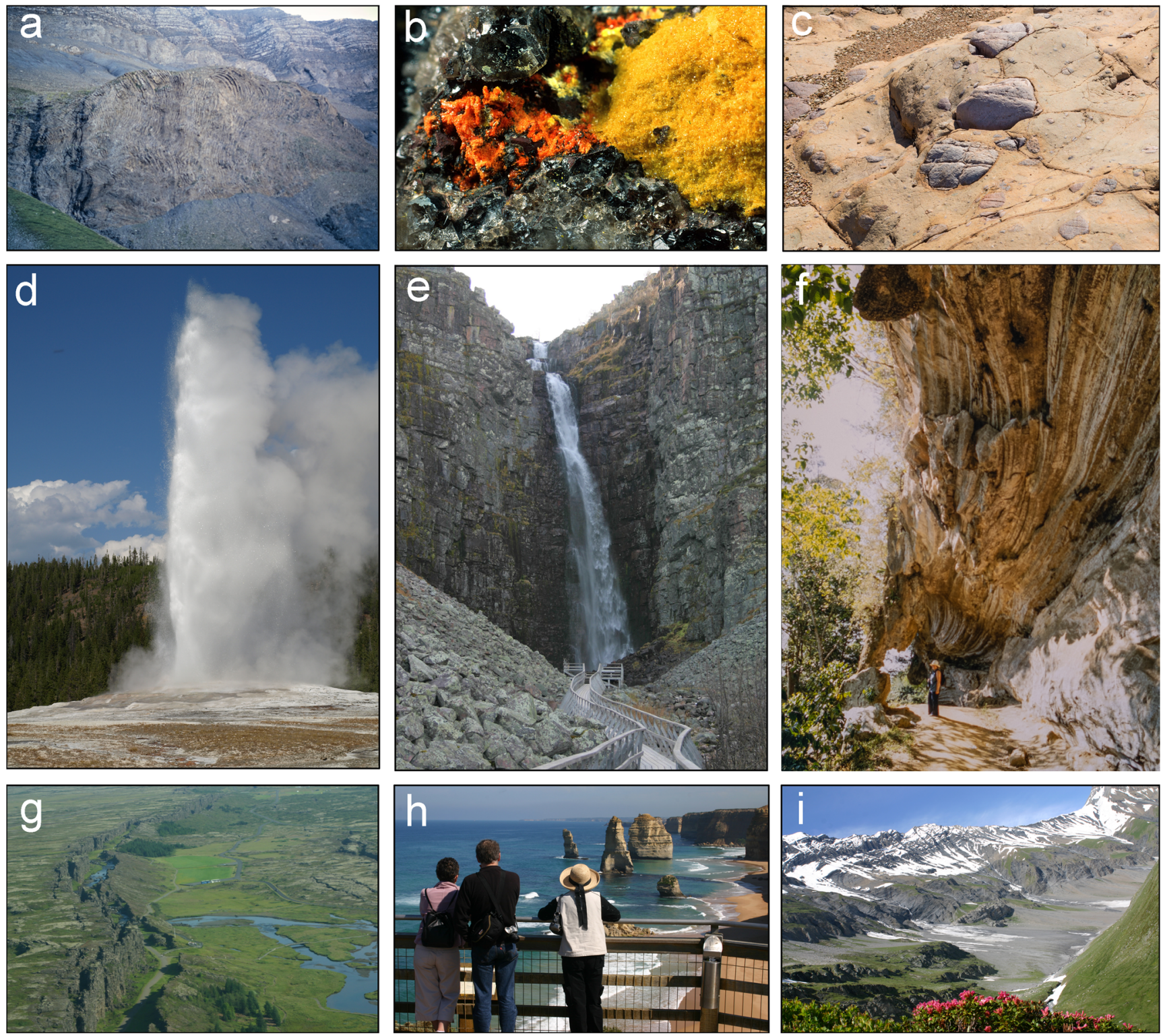

Fig. 3 Examples of site assessment criteria: a example of representativeness - folded sedimentary rocks forming mountain ranges where tectonic plates have collided, such as in the Andes, Himalayas, Rockies, and European Alps, the latter illustrated here in Ecrins National Park, France (@ Roger Crofts). b Example of rarity: Spriggite, a rare yellow mineral named after geologist Reginald Sprigg. Its type locality is Mount Painter within the Arkaroola Protection Area, Flinders Ranges, South Australia (@ Joel Brugger). c Example of the development of scientific knowledge from the study of rock formations and their origins: an ancient glacial deposit from global glaciation some 700 million years ago, often called Snowball Earth, Tillite Gorge, Arkaroola Protection Area, South Australia (@ Graeme L. Worboys). d Example of educational potential: Old Faithful Geyser and geothermal area, Yellowstone National Park and World Heritage site, USA (C) Graeme L. Worboys). e Example of safety issues: waterfall view from boardwalk

and viewing platform, Fulufjället National Park, Sweden (@ Roger Crofts). f Example of interpretative potential: an unusual rock formation at the Elephant Rock, Topes de Collantes Nature Park, Cuba (@ Roger Crofts). g Example of a geoheritage site with multiple interests: a small rift valley and a deep lake with lake-bed volcanic vents at the margin of the Eurasian/North American tectonic plates, Thingvellir National Park, Iceland. The area has significant cultural heritage interest as the location of Iceland's first parliament and is a World Heritage site (๑) Roger Crofts). h Example of accessibility: roadside access to view sea stacks at the Twelve Apostles Marine National Park, Victoria, Australia (@ Roger Crofts). i Example of the links between geodiversity and scenic value: the juxtaposition of folded sedimentary rocks, snow and ice, and alpine flora provide a scenic justification for protection, Vanoise National Park, France (@ Roger Crofts)

geoconservation areas are set out in the guidelines in some detail. Consideration should also be given to links with international designations, such as the UNESCO Global
Geoparks Network and World Heritage Sites, and possible links with biotic-focused designations, such as Biosphere Reserves and Ramsar Sites (Fig. 4). 


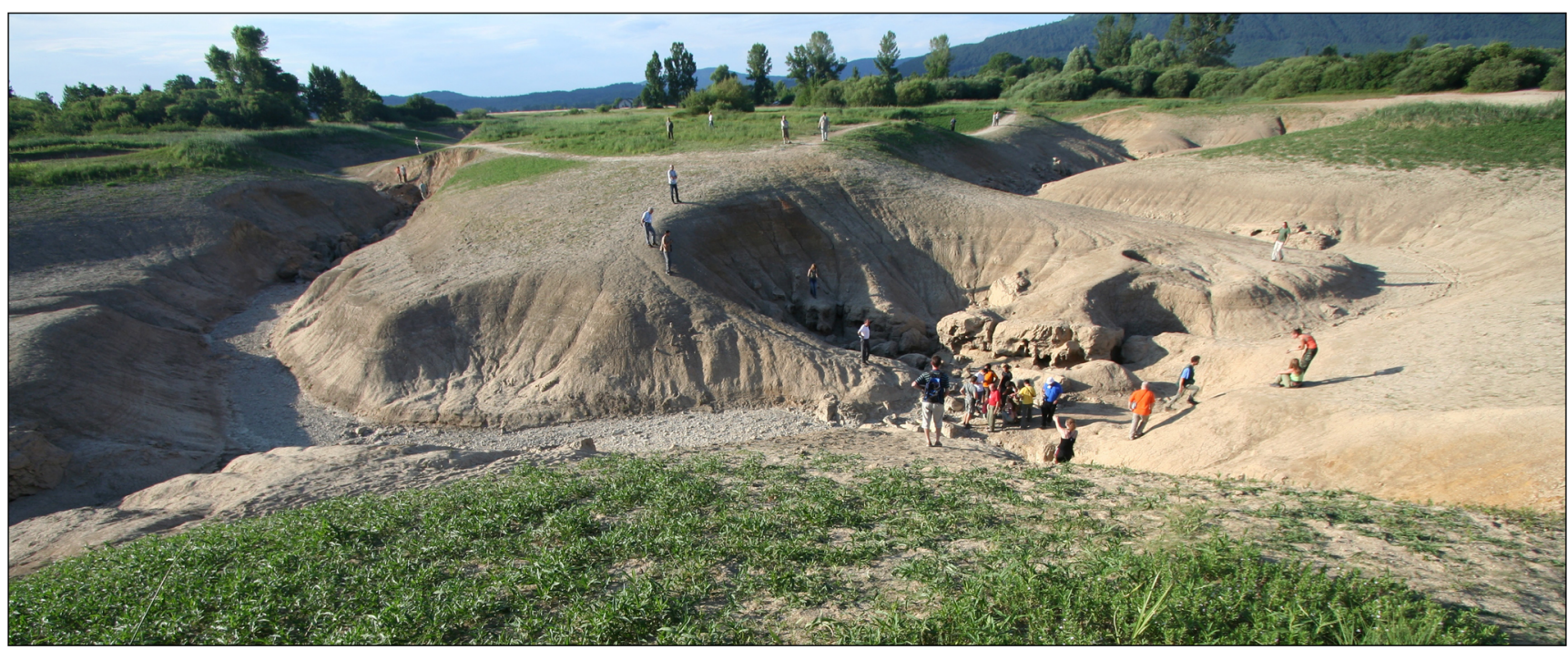

Fig. 4 A Ramsar site protected for its geoheritage interest as a seasonal lake in the globally classic Karst area of Slovenia, Cerkniško Jezero (@) John Gunn)

\section{Management of Protected and Conserved Areas}

Detailed guidance on all aspects of managing geoheritage sites and areas is provided, including management planning, managing protected area operations, incorporating spiritual and cultural values of geoheritage, and developing systems for monitoring and evaluation (Fig. 2).

Use of the classification of exposure, integrity, and finite sites (Prosser et al. 2006, 2018) is recommended as a framework for identification of typical threats and setting generic conservation and management objectives. Exposure sites contain geological features that are spatially extensive, so that if one particular site or exposure is damaged or destroyed, a comparable alternative could potentially be located nearby; integrity sites are geomorphological sites that include inactive features and/or active process systems that require the integrity of landforms and geomorphological processes to be maintained; finite sites comprise features of limited extent that would suffer irretrievable loss if any of the resource is compromised (Fig. 5).

An attributes-based system is recommended for site condition monitoring (adapted from RPDC 2003; Ellis 2004; Wignall 2019). A description of generic targets is provided. Many monitoring "use" types have been developed by protected area organisations and these are presented as generic monitoring and evaluation considerations, with specific examples provided.

In assessing different types of protected area operations, including visitor management and safety and hazard assessments, the guidelines set out the nature of the preferred action and the contribution which Earth science expertise can provide.
The cultural and spiritual symbolism of rocks and stonessuch as monoliths, megaliths, and lightning stones - is extraordinarily rich and diverse across the earth. Moreover, a vast array of precious stones and gems is used in numerous rituals and ceremonies. Sacredness, holiness, and spiritual power or significance have been attributed to numerous mountains, caves, wells, rivers, rocks and other features. For example, in Finland alone, at least 76 hills, 74 lakes, 38 mountains, 36 bays, 22 peninsulas, 18 ponds, 16 islands, 15 rivers, and 12 gorges have either the prefix "pyhä" or "hiisi" or the genitive "hiiden", meaning "sacred" or "holy" (Lounema 2003). For all these reasons, numerous geological features have been, and in many instances still are, extremely significant in cultures all over the world. It is recommended that cultural and spiritual values are included in the purposes and management of geoconservation protected and conserved areas and, where appropriate, geoheritage is included in protected areas designed for spiritual and cultural values.

Applying the IUCN Protected Area Management Categories to geoheritage is discussed, with examples provided of the types of heritage sites which conform to each of the categories. Although category III is the primary one for geoheritage conservation, all categories can have examples of geoheritage interest (Table 4).

Detailed assessments of threats and management principles are given for 4 different types of geoheritage sites and areas: caves and karst, glacial and periglacial features, palaeontological and mineral sites, and volcanic sites. For example, the following are the practical principles recommended for conserving fossil and mineral sites.

- Always encourage responsible collecting practice from protected areas 

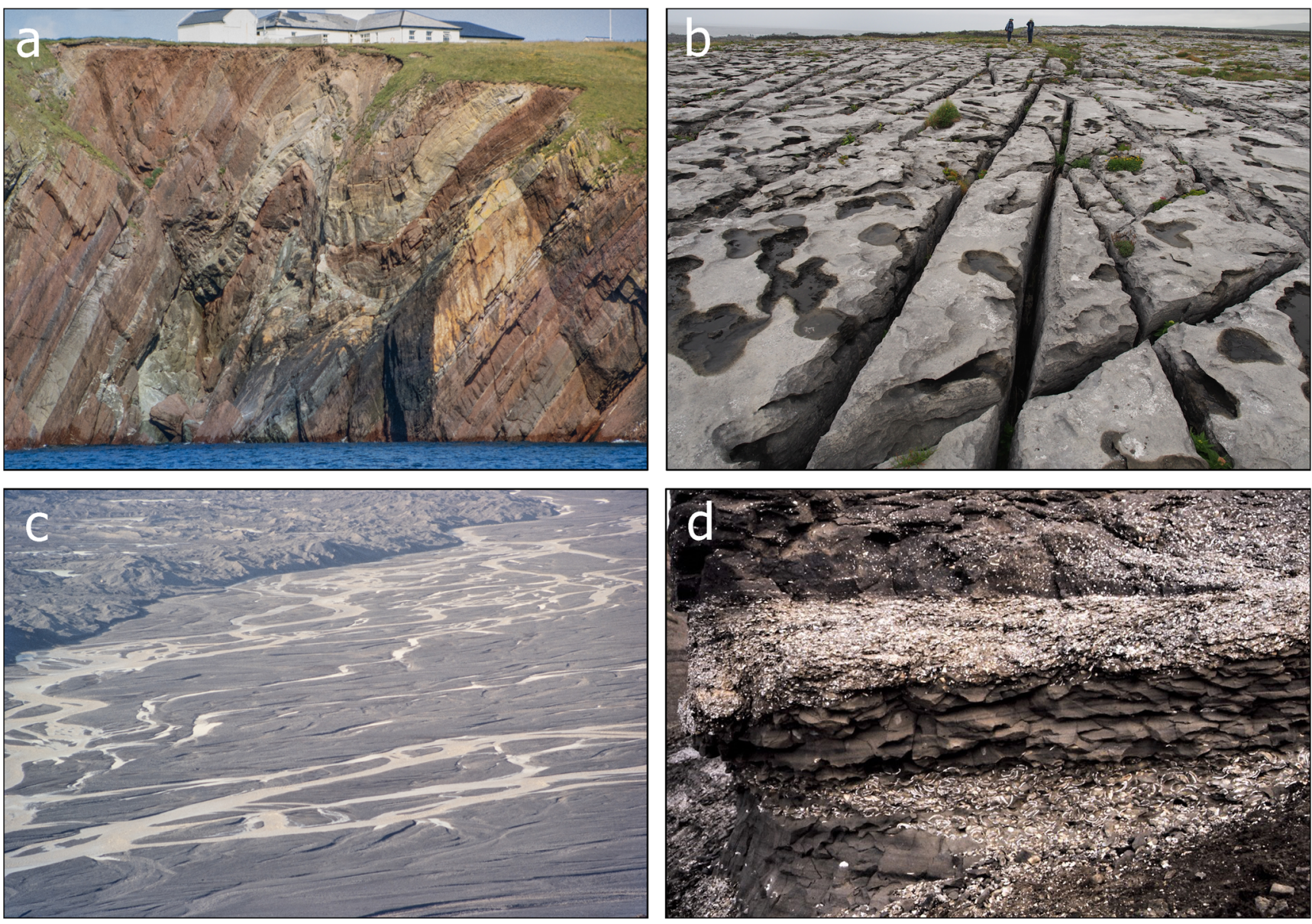

Fig. 5 Examples of exposure, integrity, and finite sites: a exposure site, Dale Peninsula, Pembrokeshire Coast National Park, Wales (@ Roger Crofts); $\mathbf{b}$ inactive integrity site, limestone pavement near Doolin in the Burren and Cliffs of Moher UNESCO Global Geopark and The Burren National Park, Ireland (@ John Gunn); c active integrity site where glacial

- Make conservation management measures proportionate to the scientific importance of the protected area and the fossils/minerals present

- Adapt conservation management to local conditions, considering issues such as the extent of the collecting resource, its rate of renewal, and the likely pressure from collecting

- Permit bona fide site-based research and study in order to facilitate the development of geoscience

- Conserve the fossil and mineral resource in situ wherever possible. In extreme circumstances, consider removal and conservation off-site in a museum, but taking care to record all contextual information before removal

- Limit any collecting to parts of the site that are the least vulnerable, or to sites that are of lesser importance, and encourage collecting from loose and waste material

- Consider burial (where the threat from weathering, erosion, or collecting cannot be managed) of some key sites to conserve the fossils and minerals in context so they are available for future study

river Jökulsá á Fjöllum emerges from Dyngjujökull glacier, Vatnajökull National Park, Iceland (@ Roger Crofts); d finite site, extremely rare occurrence in Iceland of plant fossils buried beneath younger lavas, Ytritunga Tjornes, Iceland ( Roger Crofts)

- Develop protocols to conserve fossil and mineral sites and agree a code of conduct for responsible collecting that includes amateur, academic, institutional, and commercial collectors

- Develop specimen recording schemes for key sites, encouraging collectors to share information

- Encourage regular communication between landowners and managers, collectors, museums, and researchers

- Ensure that regular site visits and monitoring are in place to assess overall condition and whether damage is occurring, with instigation of an appropriate management regime

\section{Dealing with Threats}

Geoheritage sites and features vary in their degree of sensitivity to different types of human activity and natural changes. Some are relatively robust in the face of particular threats, 
Table 4 Application of IUCN Protected Area Management Categories to geoheritage interests

\begin{tabular}{|c|c|c|}
\hline Category & Description & Geoheritage examples \\
\hline Ia Strict nature reserve & $\begin{array}{l}\text { Strictly protected for biodiversity and also possibly for } \\
\text { geological/geomorphological features, where human } \\
\text { visitation, use and impacts are controlled and limited to } \\
\text { ensure protection of the conservation values }\end{array}$ & $\begin{array}{l}\text { Surtsey, Iceland: volcanic island that emerged in 1963, with } \\
\text { access strictly limited for scientific research }\end{array}$ \\
\hline Ib Wilderness area & $\begin{array}{l}\text { Usually large unmodified or slightly modified areas, retaining } \\
\text { their natural character and influence, without permanent or } \\
\text { significant human habitation, protected and managed to } \\
\text { preserve their natural condition }\end{array}$ & $\begin{array}{l}\text { Petrified Forest Wilderness Area, USA: large area of } \\
\text { fossilised trees within restricted access wilderness area }\end{array}$ \\
\hline II National park & $\begin{array}{l}\text { Large natural or near-natural areas protecting large-scale eco- } \\
\text { logical processes with characteristic species and } \\
\text { ecosystems, which also provide environmentally and cul- } \\
\text { turally compatible spiritual, scientific, educational, } \\
\text { recreational, and visitor opportunities }\end{array}$ & $\begin{array}{l}\text { Kilimanjaro National Park, Tanzania: large central volcano in } \\
\text { the East African Rift Valley with guided access to the } \\
\text { summit }\end{array}$ \\
\hline $\begin{array}{l}\text { III Natural monument } \\
\text { or feature }\end{array}$ & $\begin{array}{l}\text { Areas to protect a specific natural monument, which can be a } \\
\text { landform, sea mount, marine cavern, geological feature } \\
\text { such as a cave, or a living feature such as an ancient grove }\end{array}$ & $\begin{array}{l}\text { Jenolan Karst Conservation Reserve, Australia: important } \\
\text { site containing Silurian age rocks with marine fossils }\end{array}$ \\
\hline $\begin{array}{l}\text { IV Habitat/species man- } \\
\text { agement area }\end{array}$ & $\begin{array}{l}\text { Areas to protect particular species or habitats, where } \\
\text { management reflects this priority; many will need regular, } \\
\text { active interventions to meet the needs of particular species } \\
\text { or habitats, but this is not a requirement of the category }\end{array}$ & $\begin{array}{l}\text { Isle of Rum, Scotland, UK: volcanic formations and } \\
\text { periglacial landforms within an area primarily for } \\
\text { protection of flora and fauna }\end{array}$ \\
\hline $\begin{array}{l}\text { V Protected landscape } \\
\text { or seascape }\end{array}$ & $\begin{array}{l}\text { Areas where the interaction of people and nature over time has } \\
\text { produced a distinct character with significant ecological, } \\
\text { biological, cultural and scenic value, and where } \\
\text { safeguarding the integrity of this interaction is vital to } \\
\text { protecting and sustaining the area and its associated nature } \\
\text { conservation and other values }\end{array}$ & $\begin{array}{l}\text { El Hierro Geopark, Canary Islands, Spain: a geologically } \\
\text { young island with well-preserved volcanic features and } \\
\text { comprising several Category V protected landscapes }\end{array}$ \\
\hline $\begin{array}{l}\text { VI Protected areas with } \\
\text { sustainable use of } \\
\text { natural resources }\end{array}$ & $\begin{array}{l}\text { Areas that conserve ecosystems, together with associated } \\
\text { cultural values and traditional natural resource management } \\
\text { systems; generally large, mainly in a natural condition, with } \\
\text { a proportion under sustainable natural resource } \\
\text { management and where low-level non-industrial natural } \\
\text { resource use compatible with nature conservation is seen as } \\
\text { one of the main aims }\end{array}$ & $\begin{array}{l}\text { Great Barrier Reef National Park, Queensland, Australia: } \\
\text { General Use Zone } \\
\text { Gros Morne World Heritage site and National Park, Canada: } \\
\text { Community Area (over 180,000 ha in extent; ancestral } \\
\text { home of the Mi'kmaq people); includes geological features } \\
\text { important for understanding the evolution of ancient } \\
\text { mountain belts and glaciation }\end{array}$ \\
\hline
\end{tabular}

Source: Crofts et al. (2020)

whereas others may be highly susceptible to damage or degradation. Use of the 10-point Tasmanian geosensitivity scale, ranging from 1 (highly sensitive) to 10 (highly robust), is recommended as it provides a means of assessing the sensitivity of geoheritage values to different types of threat (modified after Kiernan 1996 and Sharples 2002):

1. Values sensitive to inadvertent damage simply by diffuse, free-ranging pedestrian passage, even with care (e.g. fragile surfaces that may be crushed underfoot)

2. Values sensitive to effects of more focused pedestrian access (e.g. footpath erosion)

3. Values sensitive to damage by scientific or hobby collecting or deliberate vandalism or theft (e.g. some fossil or mineral collecting)

4. Values sensitive to damage by remote processes (e.g. hydrological changes upstream)

5. Values sensitive to damage by higher intensity linear impacts (e.g. vehicle tracks)
6. Values sensitive to higher intensity but shallow disturbance on site (e.g. soil erosion due to poor land management)

7. Values sensitive to deliberate linear or generalised shallow excavation (e.g. removal of tree stumps, construction of small bunds)

8. Value sensitive to major removal or addition of geomaterials (e.g. quarrying)

9. Values sensitive only to very large-scale contour change (e.g. reservoirs or major river channelisation schemes)

10. Values sensitive only to catastrophic events (e.g. major landslides or tsunamis)

The principle human-induced threats to geoheritage sites and features are assessed with examples of their impacts. Detailed assessments of threats along with best practice guidance and specific recommendations for action are given for nine situations: mineral extraction and restoration of quarries; land development and urbanisation; coastal management and 
engineering; river management and engineering; forestry and vegetation encroachment; agricultural impacts; recreation and tourism pressures; collection of specimens; and climate change and sea-level change.

Management to enhance geoheritage interests in protected and conserved areas is an integral part of geoconservation. This includes restoration where these interests have been damaged, insofar as that is possible. More widely, the requirements of geoheritage should also be incorporated in landscape restoration schemes (e.g. after mineral extraction activities have ceased) and in the restoration of rivers and coasts where natural processes have been disrupted. A now classic example of the restoration of a natural system is the removal of two dams on the Elwha River, Olympic National Park, WA, USA (https:/www.nps.gov/olym/learn/nature/elwha-ecosystemrestoration.htm). This has allowed the river to return to its natural state with the formation of sedimentary features and reinstatement of natural processes (Fig. 6).

The effects of climate change need to be addressed now and will be increasingly a focus of management attention in the future. We consider that a range of possible consequences may arise. For example, on the positive side, new exposures may be created by erosion and landslides. On the other hand, there are many consequences which will be a management challenge. For example, accelerated weathering, erosion, and vegetation growth may require increased frequency of management intervention; increased demands for hard coastal or river defences may result in sealing of exposures and disruption of natural processes; changes in land use may affect natural processes; and the locations of some exposures and dynamic landforms may change due to changing patterns of erosion and sedimentation.

Sea-level rise will have a profound effect on the functionality of some coastal systems as a consequence of enhanced coastal erosion and loss of natural buffers, such as beaches and sand dunes, with potential loss or submergence of geoheritage interests (Fig. 7a). Hard engineering does not provide a long-term solution, and managed realignment of the coastline is probably the only mechanism that is practicable. In contrast, where relative land uplift after the release of the weight of former ice sheets continues to exceed sea-level rise, new terrain will be revealed as in the High Coast/Kvarken Archipelago World Heritage site, Gulf of Bothnia, Finland, providing opportunities for new geoconservation sites (Fig. 7b).

Specific attention is given to the interaction of geodiversity and biodiversity conservation, noting where there are synergies and identifying how to approach resolution where there are management conflicts (see Crofts 2019). The conclusion is that both positive and negative interrelationships between biodiversity and geodiversity conservation should be recognised to provide the best possible outcome for nature conservation. An iterative process guided by the following questions is recommended for resolving these conflicts:

- What is the basis of the conflict between the conservation of the geoheritage and biodiversity values in and around the protected area?

- Is the conflict capable of resolution without undermining one or both sets of values, or is it more fundamental?
Fig. 6 The mouth of the Elwha River, Olympic National Park, WA, USA, in 2011 and 2014. The former shows the effect of dams upstream reducing sediment deposition. The latter shows that the river has returned to its natural state with the formation of sedimentary features and reinstatement of natural processes following removal of the dams (ㄷ) US National Park Service)
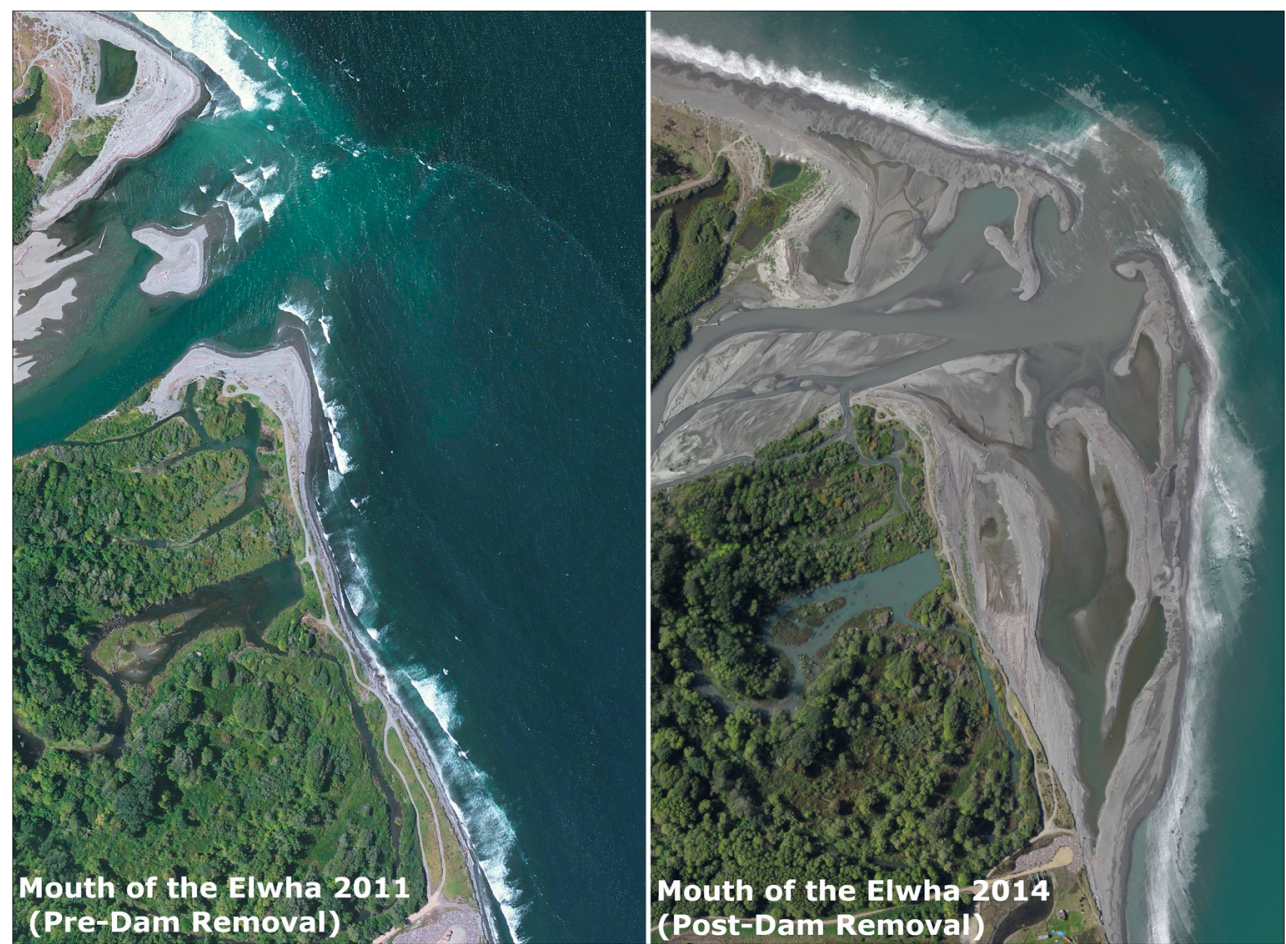

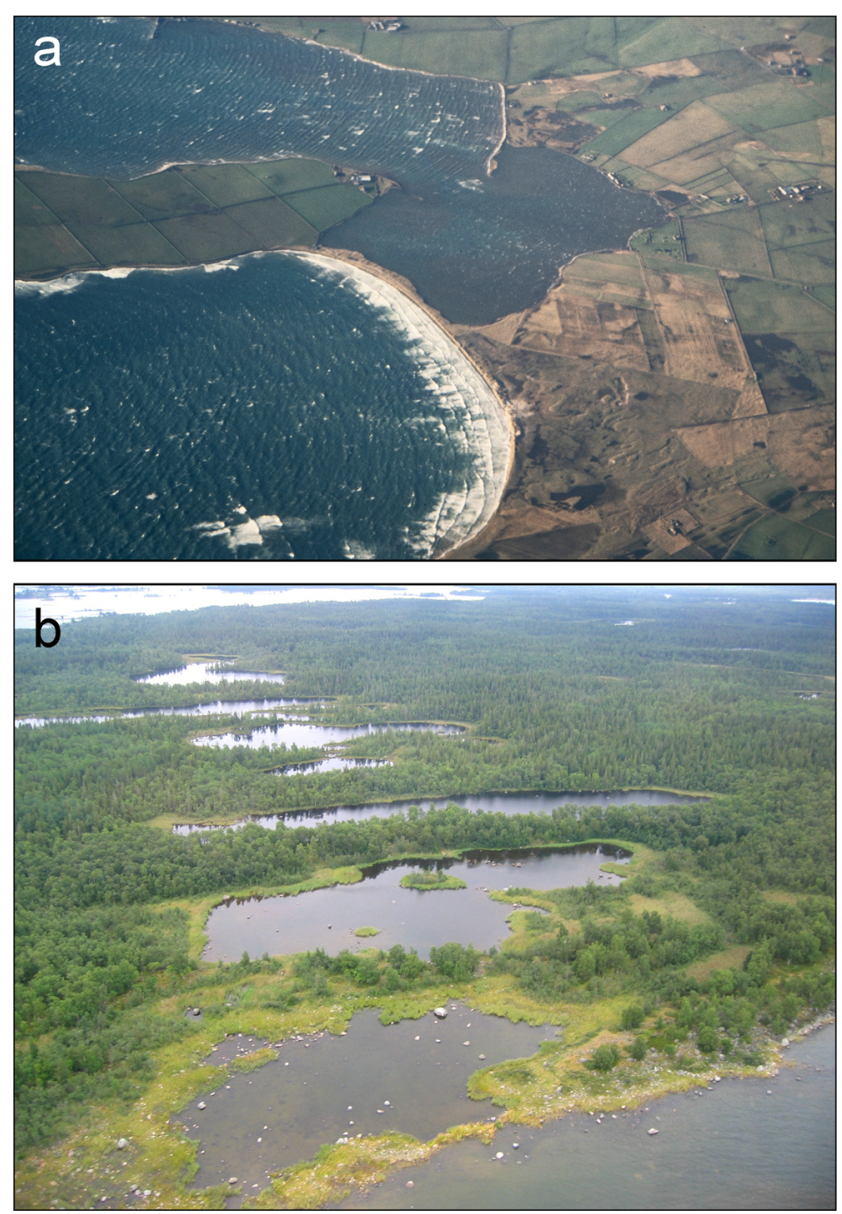

Fig. 7 Sea-level change and its implications: a coasts subject to relative sea-level rise, as in the East Sanday Coast Site of Special Scientific Interest, Orkney, Scotland, will likely experience enhanced coastal erosion and loss of natural defences, such as beaches and sand dunes, resulting in loss or submergence of geoheritage interests. Hard engineering does not provide a solution, and in many cases managed realignment of the coastline is probably the only practicable management option (C Roger Crofts); b emergent coasts resulting from land uplift after the release of the weight of former glaciers continues in some parts of the world and will continue to do so. New land will be revealed, as in the High Coast/Kvarken Archipelago World Heritage site, Gulf of Bothnia, Finland, potentially providing new geoheritage sites (@ UNESCO)

- If the latter, is one of the sets of values more important in the long term to nature conservation, and so needs to be safeguarded and the other sacrificed?

- Should the geoheritage interest be taken off-site or allowed to be obscured by vegetation growth provided that it can be periodically re-exposed for re-examination in the light of new knowledge?

\section{Education and Communication}

The guidelines explore, with examples of the use of conventional media and digital media, the philosophy and approaches

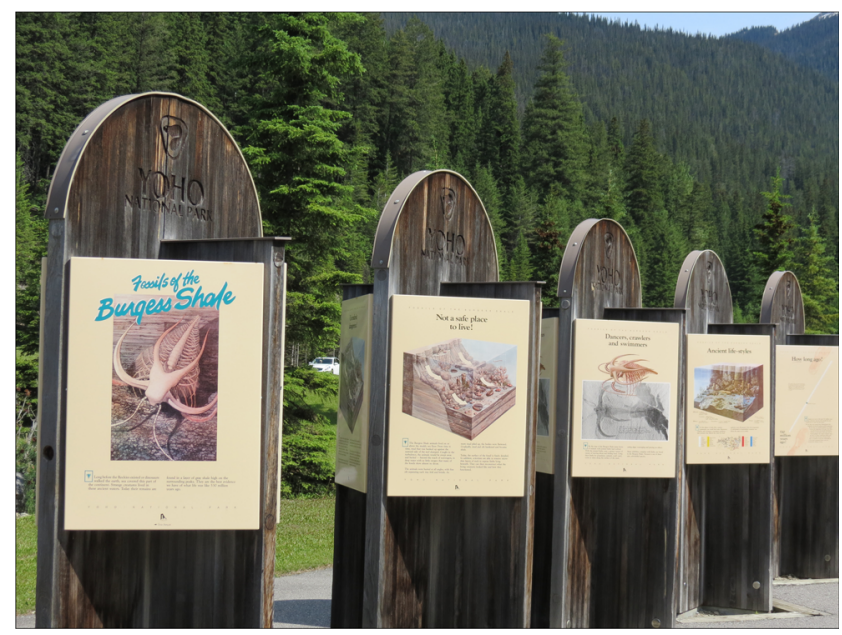

Fig. 8 Classic style of interpretation: highly accessible with clear graphics and simple statements about the Burgess Shale and evolution of life in the Cambrian period, Yoho National Park, Canada (ㄷ Roger Crofts)

of education and interpretation to increase public understanding of geoheritage in general and specifically about a particular site or area.

Communication for three purposes is described: interpretation, education, and public outreach. Interpretation is an engaging method of communication that aims to reveal the significance of a protected area's resources to the visitor, rather than just to convey factual information. Raising wider awareness and increasing involvement through education is a key part of geoconservation. Telling the geological story of a protected area is the equivalent of telling people about a slice of Earth's history. It is typically fascinating and, prepared in an interesting way, can be compelling. One of the challenges is to make the story innovative and easy to understand. The purpose should be to inform and entertain, as well as to educate, because effective geoconservation will ultimately depend on better public awareness, understanding, and support. Although all communication and education could be considered "public outreach", the guidelines focus on reaching out to communities, tourist businesses, and stakeholders who may have influence or vested interests in preserving the site, but may have little or no understanding of geoconservation. Protected areas, by definition, imply that uses which undermine the conservation goals will not be allowed. Therefore, a protected area's outreach to local communities and other regional stakeholders is often paramount to getting politicians and competing local economic interests to support conservation goals.

There are many good examples around the world. For example, classic style interpretation, highly accessible and with clear graphics and simple statements, is employed at Yoho National Park, Canada, to explain the evolution of life in the Cambrian Period as discovered in the Burgess Shale (Fig. 8). In contrast, different methods have been used at the Knockan 

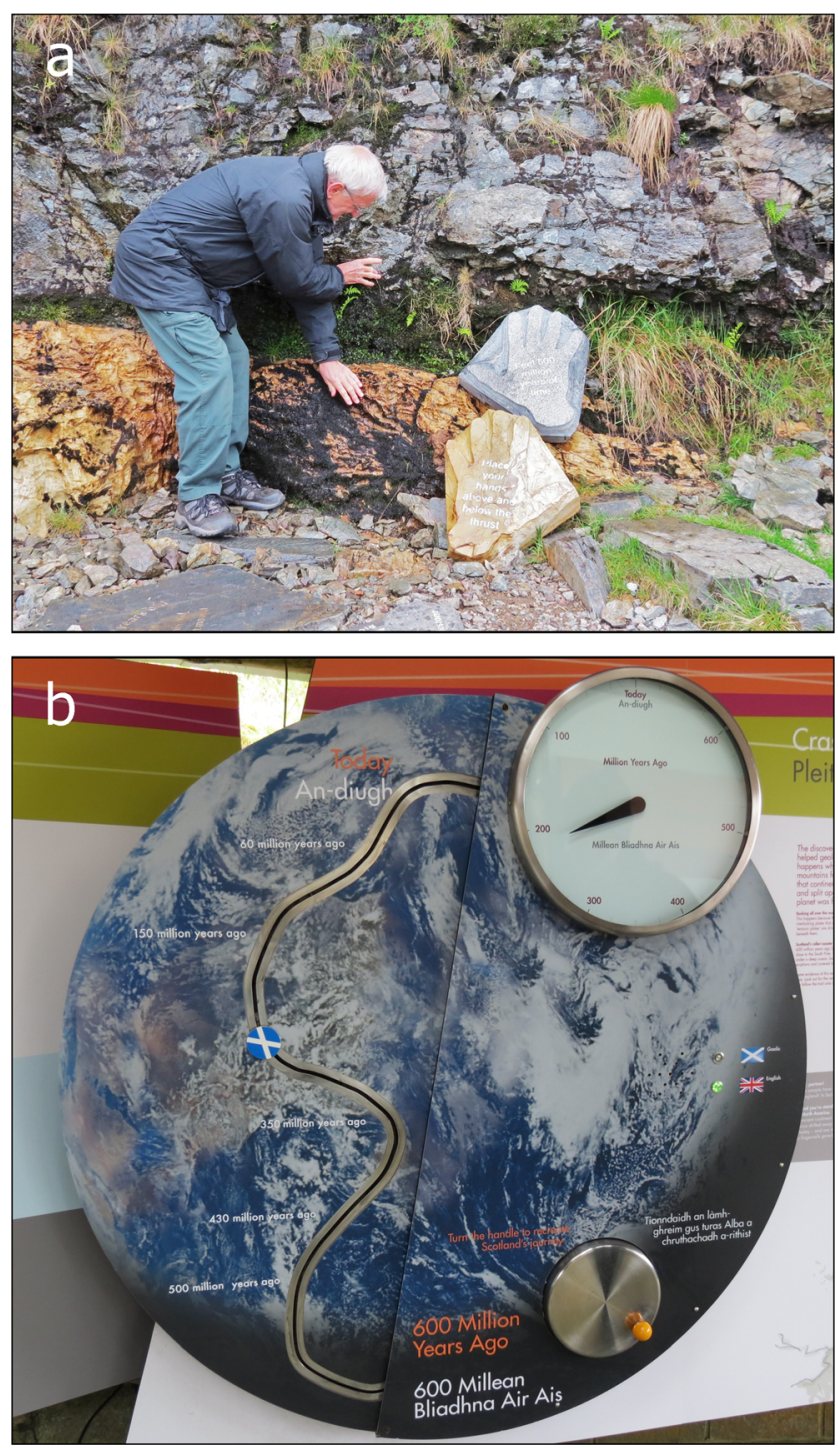

Fig. 9 Explaining the immensity of geological time at Knockan Crag National Nature Reserve, Scotland: a older rocks thrust above younger ones (@ Roger Crofts); $\mathbf{b}$ the visitor turns a handle to show how one part of the Earth's crust, Scotland, has moved over time from the southern to the northern hemisphere as a consequence of plate movements (@ Roger Crofts)

Crag National Nature Reserve, Scotland, to convey the immensity of geological time (Fig. 9).

The following general principles of geoheritage interpretation and education are provided:

1. Build interpretive planning into the design of geoconservation protected areas.

2. Avoid complex geoscience terminology and favour using everyday language, and make it informative, interesting, and entertaining.

3. Design interpretation around the user's capacity to understand the complexity of earth history and processes that are represented in a protected area.
4. Enhance understanding by linking what people see to the underlying rocks and geological structures.

5. Enhance connections by linking rocks, landforms, and soils in the protected area to the overlying flora and surface cover.

6. Provide easy-to-understand descriptions of the origins of geoheritage features in the protected area.

7. Provide information about the earth history context of the area to enhance understanding of the natural forces that have been formative in its evolution.

8. Provide visual perspectives of landscape and what lies underneath at different scales.

9. Provide connections between geoheritage in the protected area and human cultural and economic history.

\section{Help Us}

Publishing this article in Geoheritage is an important way of asking you, the reader, to help in the dissemination of this guideline to the wider conservation community as they are the target audience.

It is also a crie de coeur to ask you to provide examples of best practice and poor practice from around the world; poor practice is included because we can perhaps, in all honesty, learn more from the mistakes made than from the best examples. These examples can be provided directly to the lead author of this paper and other members of the Geoheritage Specialist Group. With this additional information, we can add to the dossier of information available and provide supplementary guidance to protected and conserved area managers and staff on the webpage of the IUCN WCPA Geoheritage Specialist Group (Geoheritage | IUCN). Most of these staff will not have access to articles in Geoheritage, and the Geoheritage Specialist Group is keen to provide as much useful information and guidance to the wider conservation planning and management community as possible.

Beyond the publication of these guidelines and the gathering of good and poor practice, there are many things that the geodiversity community and geoconservation specialists can do to promote geoconservation. First, an obvious aspect is to link geoconservation to the two major environmental crises of climate change and biodiversity loss by demonstrating in policy and practice how action for geoconservation can help to reduce the negative effects, increase resilience in species and habitats, and help mitigate and adapt to changes in climate and therefore provide more integrated and holistic solutions. Second, linking geoconservation to the achievement of the UN Sustainable Development Goals is another aspect that should be pursued internationally and nationally. Third is promotion of geoconservation through a UN International Geodiversity Day; this is currently being formulated 
following the Oxford Geoheritage Virtual Conference in May 2020. Fourth is to develop a systematic approach to the identification and development of Key Geoheritage Areas, as a complement to the Key Biodiversity Areas already in place globally. The Geoheritage Specialist Group is working on this. Fifth, with the opportunities afforded by easier global communication of ideas through the various platforms, holding webinars can help introduce protected area managers and staff to geoconservation. The authors have already held one of these webinars and more can be done. Sixth is the importance of geoconservation specialists speaking a common language with others in the nature conservation community, partly to demystify our concepts and approaches and partly to gain recognition of the importance of geoconservation as a component of nature conservation.

Acknowledgements This work was accomplished through a collaborative effort by members of the IUCN WCPA Geoheritage Specialist Group. Particular thanks go to our colleagues José Brilha, Murray Gray, John Gunn, Jonathan Larwood, Vincent Santucci, and Graeme L. Worboys. The Cultural Heritage Administration, Republic of Korea, funded the design and publication of the Guidelines on which this paper is based.

Open Access This article is licensed under a Creative Commons Attribution 4.0 International License, which permits use, sharing, adaptation, distribution and reproduction in any medium or format, as long as you give appropriate credit to the original author(s) and the source, provide a link to the Creative Commons licence, and indicate if changes were made. The images or other third party material in this article are included in the article's Creative Commons licence, unless indicated otherwise in a credit line to the material. If material is not included in the article's Creative Commons licence and your intended use is not permitted by statutory regulation or exceeds the permitted use, you will need to obtain permission directly from the copyright holder. To view a copy of this licence, visit http://creativecommons.org/licenses/by/4.0/.

\section{References}

Borrini-Feyerabend G, Hill R (2015) Governance for the conservation of nature. In: Worboys GL, Lockwood M, Kothari A, Feary S, Pulsford I (eds) Protected area governance and management. Australian National University Press, Canberra, pp 169-206 http://press-files. anu.edu.au/downloads/press/p312491/pdf/CHAPTER7.pdf

Borrini-Feyerabend G, Dudley N, Jaeger T, Lassen B, Pathak Broome N, Phillips A, Sandwith T (2013) Governance of protected areas: from understanding to action. Best Practice Protected Area Guidelines Series No. 20. IUCN, Gland, Switzerland. https://portals.iucn.org/ library/node/29138

Brilha J (2016) Inventory and quantitative assessment of geosites and geodiversity sites: a review. Geoheritage 8:119-134. https://doi. org/10.1007/s12371-014-0139-3

Brilha J (2018) Geoheritage: inventories and evaluation. In: Reynard E, Brilha J (eds) Geoheritage: assessment, protection, and management. Elsevier, Amsterdam, pp 69-85. https://doi.org/10.1016/ B978-0-12-809531-7.00004-6

Brocx M, Semeniuk V (2015) Using the Geoheritage Tool-Kit to identify inter-related geological features at various scales for designating geoparks: case studies from Western Australia. In: Errami E, Brocx M, Semeniuk V (eds) From geoheritage to geoparks: case studies from Africa and beyond. Springer, Cham, Switzerland, pp 245-259. https://doi.org/10.1007/978-3-319-10708-0_17

Crofts R (2014) Promoting geodiversity: learning lessons from biodiversity. Proc Geol Assoc 125:263-266. https://doi.org/10.1016/j. pgeola.2014.03.002

Crofts R (2018) Putting geoheritage conservation on all agendas. Geoheritage 10:231-238. https://doi.org/10.1007/s12371-0170239-y

Crofts R (2019) Linking geoconservation with biodiversity conservation in protected areas. Int J Geoheritage Parks 7:211-217. https://doi. org/10.1016/j.ijgeop.2019.12.002

Crofts R, Gordon JE (2014) Geoconservation in protected areas. PARKS 20:61-76. https://doi.org/10.2305/IUCN.CH.2014.PARKS-20-2. RC.en

Crofts R, Gordon JE (2015) Geoconservation in protected areas. In: Worboys GL, Lockwood M, Kothari A, Feary S, Pulsford I (eds) Protected area governance and management. Canberra, Australian National University Press, pp 531-568 http://press-files.anu.edu.au/ downloads/press/p312491/pdf/CHAPTER18.pdf

Crofts R, Gordon JE, Brilha J, Gray M, Gunn J, Larwood J, Santucci VL, Tormey D, Worboys GL (2020) Guidelines for geoconservation in protected areas. Best Practice Protected Area Guidelines Series No. 31. IUCN, Gland, Switzerland. https://doi.org/10.2305/IUCN.CH. 2020.PAG.31.en

Dudley N (ed) (2008) Guidelines for applying protected area management categories. IUCN, Gland, Switzerland. https://doi.org/10. 2305/IUCN.CH.2008.PAPS.2.en

Ellis N (2004) Common standards monitoring guidance for earth science sites. Joint Nature Conservation Committee, Peterborough, UK https://data.jncc.gov.uk/data/25d8bdb4-a2ad-4ae9-b341eb21daf0bc09/CSM-EarthScience-2004.pdf

García-Cortés Á, Vegas J, Carcavilla L, Díaz-Martínez E (2019) Conceptual base and methodology of the Spanish Inventory of Sites of Geological Interest IELIG. Instituto Geológico y Minero de España, Madrid 102pp

Gordon JE, Crofts R, Díaz-Martínez E (2018) Geoheritage conservation and environmental policies: retrospect and prospect. In: Reynard E, Brilha J (eds) Geoheritage: assessment, protection and management. Elsevier, Amsterdam, pp 213-235. https://doi.org/10.1016/B978-0$12-809531-7.00012-5$

Gray M (2013) Geodiversity: valuing and conserving abiotic nature, 2nd edn. Wiley-Blackwell, Chichester, UK

IUCN (2012) Resolutions and Recommendations, World Conservation Congress, Jeju, Republic of Korea, 6-15 September 2012. WCC2012-Res-048, Valuing and conserving geoheritage within the IUCN Programme 2013-2016. IUCN, Gland, Switzerland https:// portals.iucn.org/library/node/44015

IUCN (2016) Resolutions and recommendations, World Conservation Congress, Hawai ' $i$, USA. Resolution 6.083, Conservation of moveable geological heritage. IUCN, Gland, Switzerland https://portals. iucn.org/library/node/46500

IUCN (2020) Resolution on geoheritage and protected areas. WCC2020-Res-074-EN: geoheritage and protected areas. IUCN, Gland, Switzerland https://portals.iucn.org/library/node/49213

IUCN [International Union for Conservation of Nature] (2008) Resolutions and Recommendations adopted at the 4th IUCN World Conservation Congress. Resolution 4.040: conservation of geodiversity and geological heritage. IUCN, Gland, Switzerland https://portals.iucn.org/library/node/44190

IUCN-WCPA [World Commission on Protected Areas] Task Force on OECMs (2019) Recognising and reporting other effective areabased conservation measures. IUCN, Gland, Switzerland. https:// doi.org/10.2305/IUCN.CH.2019.PATRS.3.en 
Kiernan K (1996) Conserving geodiversity and geoheritage: the conservation of glacial landforms. Forest Practices Unit, Hobart, Tasmania, Australia

Lounema R (2003) Suomen kansan pyhät paikat. [Sacred Sites of the Finnish People]. Yhtyneet Kuvalehdet Oy, Hämeenlinna, Finland

Martini G, Pagés J-S (eds) (1994) Actes du premier symposium international sur la protection du patrimoine géologique, Digne-les-Bains, 11-16 juin 1991, Mémoires de la Société géologique de France (nouvelle série), p 165276 pp

Prosser CD, Murphy M, Larwood J (2006) Geological conservation: a guide to good practice. English Nature, Peterborough, UK http:// publications.naturalengland.org.uk/publication/83048

Prosser CD, Diaz-Martinez E, Larwood JG (2018) The conservation of geosites: principles and practice. In: Reynard E, Brilha J (eds) Geoheritage: assessment, protection, and management. Elsevier, Amsterdam, pp 193-212. https://doi.org/10.1016/B978-0-12809531-7.00011-3
Reynard E, Brilha J (eds) (2018) Geoheritage: assessment, protection, and management. Elsevier, Amsterdam

RPDC [Resource Planning and Development Commission] (2003) Land: geodiversity and geoconservation. Geodiversity and geoconservation issue report. In: State of the Environment Report: Tasmania. RPDC, Hobart, Tasmania, Australia https://web.archive. org/web/20130427005735/http://soer.justice.tas.gov.au/2003/lan/2/ issue/77/ataglance.php

Sharples C (2002) Concepts and principles of geoconservation. Tasmanian Parks \& Wildlife Service, Hobart, Tasmania, Australia

Wignall RML (2019) Scottish Natural Heritage earth science site condition monitoring methodology 1999-2019. Scottish Natural Heritage Research Report No. 1160. Scottish Natural Heritage, Edinburgh https://www.nature.scot/snh-research-report-1160-scottish-naturalheritage-earth-science-site-condition-monitoring 